\title{
The Caucasus in a Time of Conflict, Demographic Transition, and Economic Change
}

\author{
John O’Loughlin, Vladimir Kolossov, and Jean Radvanyi ${ }^{1}$
}

\begin{abstract}
In an introductory paper to a special issue of Eurasian Geography and Economics, the authors examine contemporary economic, social, demographic, and political developments in the Caucasus in light of their historical contexts. They emphasize the need to look beyond simple ethnic categories to understand the nature of local tensions and also propose that the profound nature of the post-Soviet upheavals has uprooted long-standing practices. The paper covers physical diversity, historical and administrative geopolitics, Stalinist deportations in the 1940s, and post-Soviet demographic and economic developments. An introduction to each of the five papers comprising the special issue follows the regional overview. Journal of Economic Literature, Classification Numbers: H11, I31, O18, P30. 2 tables, 62 references. Key words: Caucasus, Russia, multi-ethnic regions, Chechnya, Great Caucasus Range, ethnic engineering, Dagestan, de-modernization, out-migration, ethnic cleansing.
\end{abstract}

ulti-ethnic regions offer social scientists special opportunities to study the interplay of global and local processes and, in particular, to follow the evolution of complicated territorial identities. Multi-ethnic regions often play important and even determining roles in shaping contemporary geopolitical positionings of the respective states. While possessing rich and diverse natural and cultural heritages, multi-ethnic regions frequently are the foci of sharp conflicts, with repercussions far beyond their borders. But an ethnic mosaic with a "world as exhibit" view tends to freeze ethnicity into categories while ignoring what is really significant, namely, a history of institutionalization that gives rise to organizational expression and systems of political patronage. The Caucasus at the beginning of the $21^{\text {st }}$ century offers a powerful example of these themes.

${ }^{1}$ Respectively, Institute of Behavioral Science, University of Colorado, Boulder, CO 80304-0487 (johno@ colorado.edu); Institute of Geography, Russian Academy of Sciences (IGRAN), Staromonetnyy per. 29, Moscow 109017 (119017), Russia (vladk@online.ru); and National Institute of Oriental Languages and Civilizations (INALCO) and l'Observatoire des Etats post-soviétiques, 2 rue de Lille, 75343 Paris, France (radva@ext.jussieu.fr). The authors would like to thank the National Science Foundation (grant no. 0433927) and the Committee for Exploration and Research of the National Geographic Society (John O'Loughlin, PI on both grants) for the financial support that made this research and field work in the North Caucasus possible. Translation and editing of the text was by John O'Loughlin and Ted Holland and helpful comments were received from Gearóid Ó Tuathail. Thanks to Alexander Panin and Vitaliy Belozerov of Stavropol' State University for the collection of data and field assistance; to our Dagestani colleagues, Eldar Eldarov, Shakhmardan Muduyev, Sharafudin Aliyev, and Zagir Atayev for their overwhelming hospitality; to our Russian and Croatian field partners Olga Vendina and Mladen Klemencic, for their friendly and scholarly field comradeship; to Gearóid Ó Tuathail and Mike Ward, especially, for their collegiality and cooperation from the beginning of the project; and to all our survey respondents and the friendly people of the North Caucasus for their generous responses and help in our research. Nancy Thorwardson cast her minacious editorial "cold eye" on the penultimate drafts and page proofs of this and the other papers in the special issue. 
Russia, mired in the lengthy war with Chechens, has attempted to maintain its traditional influence in the region bordering its North Caucasian provinces. ${ }^{2}$ But its Georgian and Azeribaijani neighbors to the south (Transcaucasia from Moscow's point of view) have in recent years sought to detach themselves from Russian economic and political dependence and develop closer relations with the European Union (EU) and the United States. The "Rose Revolution" in Georgia at the end of 2003 and the Russian decision in 2005 under strong Western pressure to evacuate its last military bases from that country (Inozemtsev and Litovkin, 2005) show the extent of the geopolitical changes that have recently occurred. But beyond obvious geopolitical considerations, this vast mountain chain, exposed to frozen and unresolved conflicts, poses continued economic, political, and environmental challenges. The breadth of this crisis is impressively marked by characteristics that differ greatly from one locality to another due to many factors, among which the geographical and ethnic characteristics of the mountain chain play an important part. Our dual purposes in this introductory essay are to summarize the nature of the multifaceted contemporary geography of the Caucasus and also offer a background to the more specialized papers that follow on key aspects of the population, economic, environmental, and political developments in the region and its key constituent parts.

While the Caucasus is often physically represented as a unified whole, its many internal political boundaries give a different impression, one of complexity among and within states. These borders of the North Caucasian economic region within Russia were demarcated in Soviet times, and include Rostov Oblast, Krasnodar and Stavropol' krays, and the ethnic (i.e., non-Russian) republics of Adygeya, Karachayevo-Cherkessia, Kabardino-Balkaria, Chechnya-Ingushetia, and Dagestan. More recently, a wider definition has been operative, particularly in statistical analyses, which conceptualizes the area as "The Russian South," consisting of the Southern Federal District (established in May 2000 as part of a new national political restructuring) and includes, in addition to the above regions, Volgograd and Astrakhan' oblasts as well as the Republic of Kalmykia (see Druzhinin and Kolesnikov, 2000; Druzhinin, 2005).

During its history, the region has experienced periods of political fragmentation and integration under a dominant imperial power (Longuet-Marx, 1998). Over the course of 200 years, the entire Caucasus was incorporated into the Russian Empire. Given the legacy of this history, and the varied environmental and social factors that have affected the physiographically complicated region, we outline in this introduction some of the many factors that have influenced current social, economic, and political life in the Caucasus.

\section{PHYSICAL DIVERSITY}

Though we focus on the North Caucasus in this introduction and in the special issue, we connect this area to the South Caucasus, to which it is historically linked. The distribution of settlement is closely related to the relief map (see Fig. 3 in the preface to this special issue), which also strongly influences the spatial distribution of the quality of life. Geographical conditions have played a crucial role in the creation of the ethno-linguistic diversity of the region and the emergence of numerous, partly overlapping, cultural worlds, those of nomads

${ }^{2}$ Localities and regions mentioned in this introduction are identified in Figures 1 and 2 of the preface/map supplement to this special issue. 
and sedentary populations, of mountaineers and steppe-dwellers, of "indigenous" groups and of the tribes and peoples who came to the Caucasus relatively late.

The principal chain (Great Caucasus), extending about 1,500 km from west to east between the Kerch Strait and the Apsheron Peninsula, and the transverse peaks that connect the main range to the solid volcanic massif of the Low (Lesser) Caucasus towards the south, delimit several large basins. This morphological partitioning into narrow valleys, often extrusive basins and plates with ridges and mountainous slopes, contrasts the countries of the South Caucasus to the vast steppes of the north. Since antiquity, the proverbial richness of this region, emanating from Greek mythology as Colchide on the eastern shore of the Black Sea, has attracted attention from envious and powerful neighbors, obliging Caucasian peoples to seek refuge in the mountains against attacks.

As high mountains of Alpine type, the High Caucasus forms a genuine barrier: from the Mzymta River to the north of Adler in the west to the Bazaar Diouzi (4,466 m elevation) within $90 \mathrm{~km}$ of the Caspian Sea coast, the lowest pass (Krestovy pereval, Pass of the Cross) has an elevation of 2,379 $\mathrm{m}$. Dozens of peaks reach heights of more than 5,000 m, of which Mount El'brus, an extinct volcano covered with an icecap, is tallest at 5,642 $\mathrm{m}$. The border between Russia and the south of the Caucasus does not completely conform to the watershed: several areas of Georgia and Azerbaijan encroach on the northern slope of the chain whereas Krasnodar Kray, incorporating Novorossiysk and Sochi, extends south to include a large part of the southern slope along the Black Sea.

The High Caucasus possesses a double asymmetry. Tectonic characteristics account for the contrasts between the two slopes: the steep southern slope plunges directly into the Black Sea on the west, whereas the principal peaks of the east are less than $20 \mathrm{~km}$ from the plains of Alazani and Kura. By contrast, the ascent from steppe through piedmont to mountains is gradual on the northern slope, with sub-mountains and a series of full monoclines spread out largely in Dagestan. There, the sedimentary cover offers an astonishing region of enclosed folds, with alternating ridges and valleys favorable to agriculture at elevations between 1,500 and 2,000 m. In Dagestan, a system of mountain ranges, consisting of isolated and hardly accessible narrow valleys, separated by steep slopes and narrow gorges, contain almost vertical slopes that can reach heights up to $1,000 \mathrm{~m}$. This highly variegated landscape determines the relative isolation of ethno-cultural groups and their quilt-like settlement patterns (Nabiyeva, 2006). Such environmental conditions structure economic life vertically and contribute to the creation of visible cultural differences between the mountaineers, the populations living on the piedmont, and residents of the plains.

The climate multiplies these differences by contrasting the northern slope, largely opened to the cold air masses of continental Russia, and the southernmost slope protected by its sheltered position on the lee side. Since antiquity, the South Caucasus has been regarded as one of the cradles of the vine, but vineyards play only a marginal role in the north (on the piedmonts close to the Black Sea in the west and near the Caspian Sea in the east). Soviet planners were not in error when they developed cereal grains and sunflowers in the north while promoting specialized southern agriculture (wine, tea, citrus fruits, and cotton) in Georgia, Armenia, and Azerbaijan.

To this south-north contrast is added an east-west asymmetry that is based on the relative abundance of moisture. The Western Caucasus receives heavy precipitation by virtue of its location along the Black Sea coast (up to $3000 \mathrm{~mm}$ [ca. 75 inches] annually in Ajaria). Conversely, the Eastern Caucasus is dry (less than $200 \mathrm{~mm}[<10$ inches] on the steppes south of Baku). In the west, altitudinal zonation of vegetation is evident in well-defined stages, whereas Dagestan already shows the transition toward a less complex zonation typical of arid 
Central Asia. Although forests cover all the slopes to the sub-alpine level in the west, they are missing almost entirely in the east, and the lower limit of glaciers ${ }^{3}$ rises from an elevation of $1,800 \mathrm{~m}$ to more than $4,000 \mathrm{~m}$ from west to east. Pastoralism, the basis of the economy in the mountains, conforms to this contrast: the western area is devoted to cattle raising that remains quite traditional in form, based on limited movements between the alpine pastures in summer and cattle shelters in valley villages during winter. To the east of Mount El'brus, sheep husbandry dominates, based on a transhumance that lasts much longer, with most of the herds of Georgia, Azerbaijan, and Dagestan traveling from October to May to the steppes of the plains and piedmont.

Penetrating into the mountains and crossing them remains difficult; there is still no railway that crosses the main range from north to south. In the 1970s, a tunnel was started between Ingushetia and Georgia but now lies abandoned. The only roads proper ${ }^{4}$ are often closed because of heavy snow or rainstorms. During Soviet times, traffic between Russia and the Transcaucasia was made possible by circumventing the chain at its two coastal ends, involving long and expensive detours. The fact that longitudinal valleys and intra-montane basins are rarely found inside the mountain chains, and are small in size, has a major influence on human occupation. The majority of valleys are accessed only by long and difficult detours on questionable roads. This rough terrain explains the almost complete absence of cities within the mountains.

The topography of the natural landscape, and particularly the inaccessibility of many canyons and high mountain areas, has constrained human opportunities and provided conditions for development of diverse communities in relatively isolated mountain worlds. It has delimited a territorial division of labor, spurred the need for trade and cultural exchange between mountain and plains peoples, and led to the diverse ethnic composition of regional cities and favorably located foothills areas. The interdependency between mountains and plains was manifested particularly clearly in age-old traditions associated with animal husbandry. Transhumance from the high mountains to the plains furthered cultural interactions, leading to the appearance first of temporary, and subsequently permanent, multi-ethnic settlements in the foothills and on the plains.

\section{HISTORICAL AND ADMINISTRATIVE GEOPOLITICS}

The map of administrative divisions (e.g., see Figs. 1 and 2 in the preface to this special issue) only partially reflects the tangle of about 40 nationalities that dwell in the Caucasus and its environs and is significantly modified by the intersection of powerful geographical factors that were reinforced by ethnic engineering in the delineation of regional borders (Hunter, 2006). The current mosaic results from a long process of migrations, invasions, and occupations of a territory disputed by Persians, Turks, and Russians, not to mention the temporary incursions of more remote Arab and Mongolian powers or the presence from the mid19 th century of Western interests represented by German, Swedish, and French firms (Radvanyi, 2002). The integration of the Caucasian areas into the Tsarist Empire began in the 17 th century through a series of diplomatic measures. ${ }^{5}$ Later an agricultural-military

${ }^{3}$ In the Caucasus, they encompass a total area of nearly $1,300 \mathrm{~km}^{2}$.

${ }^{4}$ The Military Road of Georgia built between Vladikavkaz and Tbilisi in the $19^{\text {th }}$ century via Krestovy pereval (pass) and that of Ossetia by Roka Pass a little to the west.

${ }^{5}$ These included, for example, treaties aimed at ensuring the protection of Christian Georgians and Armenians from the Persians and Ottomans. 
occupation ensued, with the construction of the famous lines of Cossack fortified villages (stanitsy) that gradually reduced the territory of the pastoralist North Caucasians, pushing some of them into exile in the Ottoman Empire. The names of the new cities, such as Vladikavkaz ("Dominating the Caucasus," founded as a Russian fortress in 1784 near the Ossetian town of Dzaoudjikaou) or Grozny ("The Terrible [Fearsome] One," 1818) leave little doubt regarding the intentions of these settlements.

The people present today in the Caucasus belong to several linguistic families: (1) the Caucasian (a score of nationalities including Georgians in the south, and to the north, Adygeys, Kabardins, Cherkessians, and Chechens as well as 12 nationalities in Dagestan); (2) the Altaic-Turkic group (Azeris, Balkars, Karachays, Kumyks), and (3) the IndoEuropean (Russians but also Ossetians of the Iranian group and Armenians). A variety of religious affiliations overlay other national divisions. Russians, Georgians, Armenians, and the majority of Ossetians are Christian, whereas Islam gained the adherence of the majority of the other peoples. But this binary distinction is misleading: although the Georgians are Orthodox, their church has never been attached to the patriarchy of Moscow, and Armenians have adhered for centuries to their own Gregorian Eastern Christian Church (Kolossov et al., 1995). Within the Muslim population, the distinction is most dramatic between the Azeris, mainly Shiites, and the Sunni populations of Dagestan or Chechnya, organized as Sufi brotherhoods, open to much more active penetration of the new radical Islamic ideas and practices (Abdulagatov, 2006; see also maps in Beroutchachvili and Radvanyi, 1998).

An important characteristic of the ethnic structure of the Caucasus is the complexity and dynamism of ethnic identity, which results from the variations between national- and locallevel approaches to ethnic consolidation, acculturation, and assimilation, but also depend on the political and economic situation. Thus, the Andians, who speak a dialect of Avar, selfidentify as ethnic Avars, yet at the same time often distinguish themselves from the core identity of this group (Nabiyeva, 2005). Adygey peoples, although designated as titular (either alone or in combination with other peoples) in a number of republics, emphasize their closeness to or difference from other groups in a variable manner (Tishkov, 1997). Such complex identities and interrelations among ethnic groups make it difficult for ethnic activists to use the ethnic marker as a tool to achieve political objectives. Given the varied and overlapping ethnic structure of the population, political and ethno-cultural borders never completely align, although Stalin's ethnic engineering attempted to accomplish this in some circumstances. Prior to Dagestan's incorporation into the Russian Empire, the territory was organized into locally-centered economic-political units called djamaats, or free societies, which in general did not align with natural or ethno-linguistic frontiers, and remain critical for understanding the nature of Dagestani politics and society today (Ware and Kisirev, 2000).

Unlike the southern Caucasus, which during the 19th century was divided into five polyethnic territories with roughly equal population totals (Animitsa and Tertyshnyy, 1998; Tarkhov, 2001; Hille, 2003; Radvanyi, 2002), the North Caucasus encompassed numerous political districts of varying population size, with each large ethnicity assigned a clearly delimited territory. For example, Nal'chik Okrug became the Soviet republic of KabardinoBalkaria (Karavayev, 2006). In multiethnic Dagestan, during the Tsarist period, the region's internal administrative boundaries were organized to coincide with the geographical extent of the main ethnic groups, particularly in the mountains and piedmont regions.

The borders of a number of north Caucasian republics changed repeatedly until the latter half of the 1950s. Before World War II, the majority of these territories were expanded to include piedmont and plain areas with large Slavic populations. Although some scholars are 
prone to explain the complicated administrative-territorial structure of the former Soviet Union as a "divide and rule" strategy (see, e.g., Carrère d'Encosse, 1993), the reasons were, in fact, more complicated. Bolshevik leaders believed in the role of knowledge in modernizing economic production, social structures, and human consciousness. They attempted to eliminate traditional institutions and loyalties, and to delimit new territorial divisions and subdivisions on the basis of commissioned studies conducted by leading experts and planners (Hirsch, 2005). Of course, these intentions were strongly modified by considerations of "realpolitik": the objective was to integrate most of the Russian Empire using military force, intrigue, diplomacy, and local communist or nationalist organizations. Finally, this objective matched the main theoretical principles of Leninism, that a larger state is more likely to serve the interests of the proletariat.

However, geopolitical considerations alone could not ensure the remaking of the political map of a large multi-ethnic state. There was no singular vision of the ways to solve "the national question." Rather, the decisions taken by the Bolsheviks resulted from a competition between political and administrative institutions and two different concepts referred to by Francine Hirsch (2005) as the "ethnographic" and the "economic" paradigms.

The first paradigm stressed the importance of the ethnic principle of territorial delimitation and drew inspiration from the European nation-state model and the Paris Peace Conference. It was backed by the People's Commissariat for Nationality Affairs (Narkomnats), which argued that administrative-territorial divisions should conform to ethnic boundaries. Lenin also believed that nations possess observable and tangible characteristics. In a wellknown article, ${ }^{6}$ Lenin, in developing the ideas of Marx, listed national features as: (1) concentration in a single territory; (2) maintenance of general economic ties; (3) sharing a language; and (4) possessing a common psychological makeup, or specific cultural particularities. With some precision, Soviet geographers could delineate the territory where an ethnic group was centered, could calculate the number of native speakers of their language, and analyze economic connections and cultural traits. From this knowledge flowed the intention to demarcate precisely the territorial boundaries of distinct ethnic groups to the extent possible.

However, the question remained: which group had the right to form its own ethnic territory, i.e., titular administrative unit? In line with Marxist approaches, Lenin maintained that different ethnic groups were at varying stages in the process of their historical development, based on criteria that mark a fully developed nation. Thus, ethnicities from the Asian parts of Russia, according to Lenin, were still going through the feudal stage, while nations along the western border of the Russian empire were experiencing rapid capitalist development (Lenin, 1962). Therefore, the emergence of a complicated hierarchical system of ethno-territorial units, from the national okrugs up to the federal republics (SSRs), corresponded at each level not only to a definitive historical stage of national development, but also to economic, geographic, and cultural realities, as envisioned by Soviet nationality planners.

The right of nations to self-determination was (theoretically) inherent in the political structure of the Soviet Union. It was intended that these groups realize this right in the framework of the socialist federation, in which a number of these nationalities would be given their own socialist republic. Left to be decided was which ethnic groups had the right to their own ethnic republic or autonomous districts within these larger territories, and which would

${ }^{6}$ The article, entitled "The Right of Nations to Self-Determination," can be found in Lenin (1962). During the Soviet period, it was read by every high school student. 
undergo assimilation or ethnic integration. It was assumed, for example, that the sub-ethnic groups of particular nationalities, including those of Georgians and Russians, would be integrated into the main socialist nation. However, given the complicated multi-ethnic composition of the population and the inter-mixing of many ethnic groups in the former Russian Empire, the attempt to demarcate hard and fast boundaries between autonomous groups often aggravated national conflicts, as leaders of multiple ethnic groups in mixed territories made exclusive claims to these regions.

The economic paradigm, developed by Gosplan, was motivated by the "principle of economic expediency." Its advocates stated that the Soviet state should be organized within a hierarchy of special economic-administrative units at different scales. The founding fathers of Soviet human geography (e.g., Ivan Aleksandrov, Nikolay Baranskiy, and Nikolay Kolosovskiy) developed the concept of economic regionalization on the basis of the creation of efficient territorial combinations of productive forces. It served as the theoretical justification for the attempt to create, between 1924 and the early 1930s, very large, more or less selfsufficient administrative units known as krays (territories) that amalgamated "strong" and "weak" ethnic groups (peoples). In the North Caucasian krays, they included both "Russian" regions and "ethnic" areas subdivided into the constructed republics.

Geographers studied the differentiation of ethnic groups in accordance with the Leninist criteria, especially the development of ethnically defined economic life, and selfconsciousness (identity). Until the early 1930s, all administrative divisions in the Soviet Union were subject to continual adjustment; special government commissions reviewed solicitations by local party leaders regarding changes to political borders (Kolossov and Mironenko, 2001). But when Stalin definitively monopolized all political power in the Soviet Union, he no longer tolerated strong leadership of these vast territorial units, and so they were dissolved.

According to the economic paradigm, under no circumstances was it possible to unite backward regions with other backward regions. In practical terms for the North Caucasus, this meant that high mountain areas could not constitute separate territorial units and should be integrated with more developed areas on the piedmont and the plains. The re-planning of settlement during creation of the krays and autonomous republics witnessed the side-by-side juxtaposition of villages populated by Caucasians and by Russians (stanitsa Cossacks). "Biethnic" republics 7 were created on the basis of political expediency. Ignoring certain peoples who claimed their own territory, ${ }^{8}$ and dividing others, ${ }^{9}$ Stalin's policies of ethnic demarcation (razmezhevaniye) left unresolved many issues of territorial demarcation and rival claims in the successor states of the Soviet Union.

\section{DELAYED IMPACTS OF STALINIST DEPORTATIONS AND ETHNIC ENGINEERING}

Significant changes to the ethnically engineered political map of the Caucasus resulted from the Stalinist deportations of the 1940s. Although deportations continued until the end of the decade (Polyan, 2001), they reached their apex in 1944, when a number of Caucasian

${ }^{7}$ E.g., of Kabards and Balkars, Karachays and Cherkessians, as well as the now-splintered republic of the Chechens and Ingush.

${ }^{8}$ E.g., the Lezghins, whose concentration straddles the current border of Dagestan and Azerbaijan.

${ }^{9}$ E.g., the Ossetians, who possess two territories on either side of the crest of the Great Caucasus (the Republic of North Ossetia in Russia, and the South Ossetian autonomous region in Georgia). 
peoples were accused of collaborating with the Nazis and subsequently resettled in Siberia and Kazakhstan. Autonomous territories were either redesigned or eliminated altogether. In the course of three days during February 1944, 478,000 Chechens and Ingush were deported. The Chechen-Ingush Autonomous Soviet Socialist Republic (ASSR) was abolished, its territory divided between Georgia and neighboring regions of the Russian Soviet Federal Socialist Republic (RSFSR), part of which was incorporated into the newly created Grozny Oblast. When in 1956 (after Stalin's death in 1953), the deported populations were rehabilitated and allowed to return to the Caucasus, their settlements had been occupied. A well-known decree by the USSR Supreme Soviet, issued in April 1991 (in the last months of the country's existence), supported territorial rehabilitation of these peoples, but in the succeeding years, such rehabilitation failed to occur (Mukomel, 2005). The return of Ingush populations to Prigorodnyy Rayon in North Ossetia led to the bloody Ossetian-Ingush conflict of 1992, which continued until the intervention by the Russian military. The majority of Ingush refugees, who had fled their auls (villages) in the rayon, have yet to return. In 1992, the Lak national movement leadership in Dagestan decided to support the government's plan to allow the resettlement of the Chechen populations deported from Novolakskiy Rayon (current name), and a number of Laks residing in the rayon were subsequently relocated to make way for the returning Chechens; ${ }^{10}$ however, the return of the Chechens to this rayon is still far from complete.

The months leading up to the breakup of the Soviet Union in 1991 witnessed a revival of ethnic movements and increased incidence of interethnic conflict, the potential for which was promoted by the territorial boundaries imposed by the Soviet state and the legacy of the deportations. Ethnic activists among the returnees demanded the complete territorial rehabilitation of the deported populations, the creation of new ethno-territorial units, or the return to the borders existing at the time of World War II (Kolossov et al., 1992; Brunet et al., 1995). As during the early years of the Soviet state, attempts to unite the mountain groups emerged.

In the early 1990s, the Chechen leadership, headed by the former Soviet general Dzhokhar Dudayev, declared independence for Chechnya (Ichkeria), carved out from the Chechen-Ingush ASSR. At the end of 1994, the Yel'tsin administration attempted to restrain the separatists by military force. The first Chechen war, which continued until the middle of 1996, ended as an embarrassing defeat for the Russian military. The decision regarding the status of Chechnya was deferred, and the Republic of Ichkeria gained de facto independence. However, internal strife among the Chechens inhibited any form of central governance, with the territory controlled by the field commanders cum warlords. The period 1996-1999 also saw the attempt of political opportunists, capitalizing on the slogans of Islamic fundamentalism, to reconstitute a North Caucasian Imamate, first established during the Caucasian Wars of the 19th century, and including much of Dagestan. The attack against neighboring Dagestan in early autumn 1999 served as the impetus for the second Chechen War, which resulted in Grozny's control by the segment of Chechens loyal to Moscow (Sakwa, 2005). Human rights violations on both sides are frequent and widely reported (Tishkov, 1999, 2001, 2005; Mendelson, 2006).

Whereas many observers, Russian as well as Western, anticipated a domino effect of the Chechen conflict, it has not occurred, although periodic violence has spilled over into adjoining territories (Kramer, 2005). The neighbors do not accept the Islamist hegemony that the

${ }^{10}$ See Figures 2 and 4 in the preface/map supplement to this special issue for locations and Eldarov et al. (2007, p. 231) for further details. 
radical Chechens propose. Playing on the armed threats from radicals and with promises of development aid, Moscow has up to now avoided contagion beyond Chechnya, but the situation remains fragile. In Dagestan and in Karachayevo-Cherkessia, the threat of a political or social explosion, provoked by generalized corruption and periodic actions by terrorist groups, is omnipresent.

The post-Soviet conflicts also serve to illustrate the interconnection and interdependence between the North and South Caucasus. The autonomous status of South Ossetia was eliminated by a newly independent Georgia, and in the course of the bloody conflict with the central government, South Ossetia established itself as a break-away republic. Refugees from the conflict flooded into North Ossetia. The influx of refugees not only complicated the socio-economic situation in the republic during the difficult period of transition, but also raised nationalist sentiment, leading to increased ethnic tensions.

Despite the cartography of political borders drawn by Stalin along ethnic lines and daily reports of violence in and around Chechnya, most communities in the North Caucasus remain mixed. Derbent in Dagestan is exemplary of mixed ethnic urban settlement. In this ancient city, where mountains front on the Caspian Sea, Russian Orthodox and Armenian Gregorian churches are found side by side with synagogues ${ }^{11}$ and old Sunni and Shiite mosques. The countryside is more ethnically homogenous, although various ethnic groups often live in close proximity to one another. A prime example is Turkmenskiy Rayon in northeastern Stavropol' Kray. ${ }^{12}$

Three population/political developments over the past 15 years illustrate the close North-South ethnic linkages across the Caucasus (Lynch, 2003). As in other mountainous regions of the world, economic interactions conditioned by natural resource limitations and scarce arable land in the mountains and (for those who live in the foothills and on the plains) limited water supplies result in discord and conflict among ethnic groups. The conflict between Georgia and the South Ossetians coincided with the North Ossetian campaign against the Ingush for control of territory (Prigorodnyy Rayon, near the capital of Vladikavkaz) where the North Ossetian authorities had settled refugees from South Ossetia. Secondly, in 1992, immediately after the Soviet Union's collapse, war broke out between the central government of Georgia, which was attempting to centralize its political power, and the northwestern region of Abkhazia, which demanded greater autonomy. The Abkhaz separatists were supported by ethnic Adygeys in Russia, who provided military supplies and troops from the northern side of the Caucasian chain. Thirdly, throughout the North Caucasus, there is a significant Armenian population, including refugees and economic migrants, who support close relations with their homeland to the south. Given these interrelationships and other similar linkages, the North and South Caucasus can today be conceived of as a single ethnopolitical system.

\section{POST-SOVIET GEO-DEMOGRAPHIC DEVELOPMENTS}

Despite frequent arguments about scarce water and pasture access, about militia raids and population removals, or even pogroms or local wars, the Caucasian populations have traditionally lived together peacefully. In such polyethnic societies, demographic processes are

${ }^{11}$ There remain some communities of Mountain Jews (Tats) of Iranophone heritage.

${ }^{12}$ So named because it is home to the only native group of Turkmen in the European part of Russia; their ancestors moved there from Central Asia in the mid-17th century. Close to Turkmen villages are those inhabited by Nogays, Tatars, and Russians. 
reflected in social well-being and identity, particularly differences among ethnic groups in terms of history, identities, and migration.

The modern population history of the North Caucasus can be clearly divided into two periods. The first lasted approximately 150 years - from the beginning of the 19th century to the start of the 1960s — and was defined by the gradual influx of Russian, Slavic, and other non-Caucasian peoples into the region. This process was initially due to the agricultural development of the steppes and piedmont by settlers from the interior regions of Russia. A subsequent industrialization and social modernization that occurred during the Soviet period required the in-migration of qualified cadres and bureaucrats, usually ethnic Russians, from different parts of the country.

The second period that began during the second half of the 1960s has seen an absolute decline in the number of Russians, both in the national republics and in the North Caucasus as a whole. Native ethnic groups underwent the demographic transition somewhat later than the Russian population, particularly in Chechnya and Dagestan. In Dagestan, a steady reduction in birthrates was recorded only at the beginning of the 1990s. Natural increase there has remained very high, although it has been halved during the post-Soviet years, to 10 per 1000 people. At the same time, traditionally "Russian" regions of the North Caucasus experienced demographic crises significantly later than other territories in European Russia. But even in these areas, the mortality rate has exceeded the birth rate since the beginning of the 1990s.

Therefore, the North Caucasus today maintains significant ethnic and territorial differences in the natural dynamics of its population. The labor surplus, particularly in rural areas, was already evident in the "ethnic" part of the region during Soviet times, forcing part of the male population to move for seasonal jobs in construction and other industries. Sheep herding in the "Russian" regions of the southern part of the Russian Federation continued, thanks to the in-migration of Chechen and Dagestani pastoralists. They first lived in temporary settlements, which subsequently developed into permanent communities as the herdsmen later returned with their families.

After the dissolution of the Soviet Union, the subsequent economic crisis increased the ratio of North Caucasians in the labor markets of the neighboring Russian regions, as well as in Russia as a whole. Furthermore, violent conflicts, in particular the war in Chechnya, led to a sharp increase in the number of North Caucasian out-migrants: large Chechen communities formed not only in Moscow, but in the majority of the larger cities across the country. A great number of Chechen refugees still live in camps, located primarily in Ingushetia.

With the partial recovery of the economy from the crisis of 1998, a number of major cities and regions in Russia experienced labor shortages (especially when relatively unskilled workers were needed) in the construction, farming, and industrial sectors. However, in the culture of the North Caucasians, the traditions of industrial labor have failed to take root (Denisova and Ulanov, 2003). Market processes of structural transition in the Russian economy have resulted in the shrinking of the workforce in declining industries and the sharp expansion of employment in retail trade and personal services, characterized by a high turnover of capital and rate of profit. Taking advantage of these new opportunities, many migrants from the North Caucasus engaged in trade and various services-from restaurants to automobile repair (Mukomel, 2005).

Out-migrants from Chechnya, Dagestan, Armenia, and other parts of the North Caucasus have settled in rural areas in neighboring "Russian" regions, where both land and houses became available due to Russian population loss. The changing ethnic composition of these dominantly Russian settlements has, in turn, caused the younger, more adaptable cohort of the Russian population to leave. In a comparatively short period of time, the ethnic 
structure of the entire region changed so dramatically that the idea of "derussification" of the North Caucasus has entered into political discourse (see Vendina et al., 2007, p. 197 in this special issue).

In the metropolitan areas of the North Caucasus, the closing of large-scale industrial facilities, predominantly employing Russians, prompted an ethnically specific employment crisis. It became difficult for ethnic Russians in the republics to find employment in other sectors, due to escalation of interethnic competition that had begun even before the dissolution of the Soviet Union. A number of researchers (Kaiser, 1994; Drobizheva et al., 1996; Tishkov, 1997) explain this competition and the ensuing "ethnic restratification" by rising levels of education among the titular nationalities and the strengthening of their political and intellectual elite - a process facilitated by political liberalization late in the Soviet period. In an environment of economic disruption and transition, the ethnic solidarity of the Caucasian populations and supportive elements of their native organizational structures became important resources for survival. ${ }^{13}$ A cycle developed in which difficulties in finding employment resulted in out-migration of Russians and members of other non-titular nationalities. This, in turn, produced changes in the local cultural mix and encouraged further in-migration by Caucasian nationalities. Overall, the Russian population in the republics began to decline not only in rural areas, but also in the main cities.

If out-migration from the ethnic republics, whether temporary or permanent, served to partially resolve the problem of surplus labor and significantly lowered population growth rates, it produced a quite different effect in the "Russian" regions. Here the arrival of migrants compensated for high mortality during the post-Soviet transition period. Krasnodar and Stavropol' krays, with their temperate climates and favorable natural conditions, were the most attractive destinations for migrants. These areas were swept by large waves of repatriated Russians from the former Soviet republics (from the South Caucasus, but especially from Kazakhstan and Central Asia) as well as from parts of the Russian Federation, including Chechnya and other republics in the North Caucasus, as well as northern and eastern parts of the country, which were also de-populating (Ryazantsev, 2003).

The character of migration to the "Russian regions" has changed over time as well. The highest levels of migration to both the "Russian" regions of the North Caucasus and Russia as a whole occurred in 1994. Between 1991 and 1995, the migration surplus in the three "Russian" regions (Rostov Oblast and Krasnodar and Stavropol' krays) was 775,000 people (Druzhinin, 2005). In addition to ethnic Russians, the number of Armenians has risen substantially in these territories, and includes those who left Azerbaijan following the violent events in Sumqayit and Baku (Azerbaijan) in 1989 and 1990, and the conflict in NagornoKarabakh, as well as from Armenia proper after the 1988 earthquake and significant deterioration of the economic situation (e.g., see Rowland, 2007). Migrating Armenians relied on the support of an Armenian community that was long established in many cities in the North Caucasus (Belozerov et al., 1998; Kolossov et al., 1998).

Between 1991 and 1995, the stream of migrants (especially Azeris, Chechens, and Dagestanis) into the Russian regions steadily waned and no longer masked population decline due to mortality. Accompanying the decline in migration intensity was a change in the motivations for migration as economic, as opposed to "political," motives gradually came to the forefront. By the middle of the present decade, depopulation had occurred in 10 of the

${ }^{13}$ Unlike the Caucasian peoples, ethnic Russians in the large cities in the North Caucasus for the most part were unable to rely on help from rural relatives and their supplies of food (Belozerov, 2000), as the number of Russians in the region's rural areas had been declining for several decades. 
13 regions of the Southern Federal District. Since 2000, populations have grown only in Dagestan, Ingushetia, and Chechnya, though the reliability of statistical data for the latter republic is questionable (Maksudov, 2005).

Using detailed data at the city and regional scales from censuses conducted between 1970 and 2002, Vitaliy Belozerov (2005) identified two primary trends affecting the ethnic republics of the North Caucasus. On the one hand, the number of ethnic Russians has been sharply declining and native populations have substantially increased while, at the same time, mountainous areas within ethnic republics have been becoming more ethnically homogeneous. Conversely, the process of migration from mountains to lowlands, observable in many parts of the world, continues. Specifically in Dagestan, more than 200,000 people were forcibly moved through deportations and "organized resettlement" of mountaineers, resulting in the formation of 75 new village centers with ethnically-mixed populations (Muduyev, 2003). In the last decade, the republics of the North Caucasus, in particular Dagestan, have experienced "explosive urbanization." Makhachkala is now the fastest-growing city in Russia, as its metropolitan area approaches 700,000 inhabitants, and one-third of the republic's total population now lives in or near the capital. New settlements and cities quickly evolve into unique ethnic "melting pots," where traditional ethnic foundations are weakened and eventually disintegrate (see Eldarov et al., 2007, p. 237 in this issue).

Eager at all costs to prevent the Chechen conflict from spreading to neighboring republics, Russian Presidents Yel'tsin and Putin appear to have tolerated the emergence in the region of an entire series of deviant behaviors: generalized corruption, clan hegemony, and nepotism here have reached extreme levels, which greatly limit the federal center's exercise of political control. Federal financing and subsidies are collected systematically by the clans for their own purposes, to the detriment of regional economic needs and those of a poor population whose standard of living is thus degraded, making the calls of nationalist or Islamist movements all the more appealing. This problem has reached such a level that President Putin's special representative to the region, Dimitry Kozak, proposed in 2005 to supervise the actions of the presidents of these ethnic republics (e.g., see Nikitina et al., 2005), but this suggestion has not been pursued. It is still too early to gauge any possible reforms from recent changes in the leaderships of several republics (Dagestan, Ingushetia, North Ossetia, Kabardino-Balkaria, and, as this issue goes to press, Chechnya).$^{14}$

The North Caucasus region is now experiencing a dramatic renaissance in Islamic cultures and practices that take on different characters in different places. During the Soviet period, there were 27 mosques in Dagestan; only three of these were located in cities. As of late 2006 there were nearly 1,800 mosques in the republic and a significant Islamic educational system has developed. One-eighth of the adult Dagestani population has completed the Hajj to Mecca and there is a growing importance of international religious influences in Dagestan and the other republics, in particular the presence of foreign religious leaders (Abdulagatov, 2006; Matsuzato and Ibragimov, 2005; Ware et al., 2003).

Another recent trend is the relative decline in the prevalence of the Russian language in the North Caucasian republics, particularly among youths in isolated monoethnic communities. According to the 2002 Russian census, 15 percent of Avars, 13 percent of Dargins, and nearly 20 percent of Chechens are unable to communicate in Russian (Rosstat, 2004a). Russians, in turn, are rarely conversant in native Caucasian languages. An ideological

${ }^{14}$ The resignation of Chechnya's President Alu D. Alkhanov was accepted on February 15, 2007, making the republic's de facto leader, Prime Minister Ramzan Kadyrov, the acting president (Myers, 2007a). Kadyrov was officially appointed as Chechnya's president a few weeks later (Myers, 2007b). 
vacuum, formed after the discrediting of the Communist ideology and the breakdown of the Communist Party's ideological system, has developed. Levels of communication and exchange have declined as well. ${ }^{15}$ The spatial mobility of scientific, technical, and administrative personnel in the Caucasus has thus significantly decreased.

Despite the dramatic cultural and religious revival in the Caucasus since the demise of the Soviet Union, the legacy of the past is also strong. Russian remains the dominant form of interethnic communication. The experience of many decades and even centuries of ethnic coexistence, particularly during the Soviet period, serve to tie together powerfully the political space of the North Caucasus. Commonalities remain in the system of higher education, and the information space is dominated by the popular federal television channels that reach even the most remote mountain areas. A mass labor migration of Caucasians to Central Russia also continues to stimulate cultural interaction.

\section{DE-MODERNIZATION AND UNEVEN DEVELOPMENT}

Rather than explaining depopulation as the result of ethnic tensions in the North Caucasus, these conjoint issues must both be related to the difficult economic situation in the region, particularly in the national republics. Despite the outflow of migrants, the percentage of Russia's total population in the North Caucasian republics is increasing, while the ratio that these republics contributes to the GDP is contracting. The "weight" of the region in demographic terms is nearly twice its contribution to GDP. ${ }^{16}$ Although this figure reflects only offical data, ${ }^{17}$ the weakness of the republics' economies is clearly reflected in the failure to provide even minimal social needs from the republican budget. Subventions from the federal government made almost 75 percent of the 2006 budgets of North Caucasian republics. The long-term practice of subsidization has bred a welfare mentality among the republican leadership but, at the same time, federal subsidies have provided elites a powerful instrument for strengthening their personal power through the reallocation of the funds from Moscow, deepening the problem of corruption.

The crisis of the transition period demonstrated clearly the industrial weakness of the North Caucasus, when compared to other parts of the country. In the new market environment, industrial facilities folded or were forced to sharply scale back production. First and foremost among the plants shutting down were those employing relatively advanced technology, particularly those connected to the Soviet military-industrial complex. Except for the area of Novorossiysk, a major export port and pipeline terminus for Kazakh oil and Siberian gas, the area has lost much of its oil/gas-related activity with the destruction of the oil refining/petrochemical complex at Grozny along the southern pipeline from Azerbaijan. Deindustrialization has severely affected the functions and social structure of the capitals and other important cities in the republics. In the final two to three decades of the Soviet state, facilities for the electronics industry and other machinery plants were located in these territories. Branches of these industries, opened in mountainous areas of Dagestan and other republics, have closed first during the economic downturn.

15The circulation of national newspapers has decreased in the region more rapidly than in the rest of Russia. And for economic reasons, it has become impossible to bring students from the national republics to Moscow and other major Russian cities for higher education.

${ }^{16}$ The North Caucasus region as defined here contained 13.1 percent of Russia's population in 2004, but accounted for only 7.5 percent of its GDP (Rosstat, 2006).

${ }^{17}$ It is estimated that up to 70 percent of economic exchanges occur on the black market. 
With industrial production declining more drastically than in Russia as a whole, the North Caucasian republics' contribution to Russian industry has now fallen to a minuscule 0.4 percent. This decline has resulted in a sharp drop in demand for qualified engineertechnician cadres, among whom Russian and other non-titular nationalities were predominant. The dismantling of industry promoted by the trend toward de-modernization in the social structure of society as a whole - a kind of "ruralization" — occurred not only in a quantitative, but also in a qualitative sense. Statistically, the North Caucasus retains a decidedly rural character. The proportion of rural residents in the region's total population was 45.9 percent at the beginning of 2006, compared with an average 27.1 percent in the Russian Federation; Krasnodar (47.4 percent) and Stavropol' (43.6 percent) krays rank first and third in this statistic among all "Russian" regions of the country (Rosstat, 2004a). To some extent this is understandable given the favorable climate for agriculture in much of the lowland part of the region. Nonetheless, in general, rural populations are often less educated and poorer, and the lack of opportunities in rural areas is highly correlated to unemployment. These difficult economic circumstances do not help mitigate interethnic tension in a region where extended family ties are important to quality of daily life.

The direct and indirect externalities of the Chechen conflict affect the entire Caucasus region. ${ }^{18}$ Even as federal authorities in Moscow speak of standardization and rebuilding of the destroyed republic, reconstituting the major industrial node of Grozny with its refineries and military-industrial complex is not yet on the table. Additionally, the two Chechen wars and their refugees have had contradictory effects on adjoining areas. While there has been construction of infrastructure related to the battle against terrorism, the total assessment is rather negative because investors have hesitated to become involved in the North Caucasian republics.

After the financial crisis of 1998 and the resumption of economic growth, there has been a growing dependence in post-communist societies on tradable products for consumptionmost of all, food commodities. This new consumer demand serves as an important stimulus for the development of agro-industrial production in the northern part of the North Caucasus - i.e., Rostov Oblast, Stavropol' Kray, and, particularly, in the Kuban (Krasnodar Kray). During the Soviet period, Krasnodar Kray was one of the leading producers of cereal grains, sunflowers, sugar beets, milk, meat, and the only producer of a number of subtropical fruits. In the steppes of the North Caucasus, well-known in Russia for their "black soil" (chernozem) and high yields, large agricultural enterprises have been established in place of the former kolkhozy and sovkhozy. In food production, Soviet levels of production were quickly matched, and subsequently surpassed (Table 1).

The benefits from increasing consumption of domestically produced food and other commodities have had a much weaker impact on the economies of the North Caucasian ethnic republics. After the collapse of the kolkhoz system, mountain farms' access to labor and markets proved too limited and difficult to allow any substantial increases in income under market processes. An exception is the labor-intensive commercial production of vegetables and melons, particularly in Dagestan, where entire rayons now specialize in exporting such produce to central Russia. In North Ossetia, Karachayevo-Cherkessia, and KabardinoBalkaria, the production of mineral water, alcoholic beverages, and vodka has proven profitable, and has significantly expanded as well. ${ }^{19}$

${ }^{18}$ For more on this subject, see the paper by Vendina et al. (2007) in this issue.

${ }^{19}$ North Ossetia's share in the total Russian production of vodka and spirits grew from 1.4 percent in 1990 to 7.1 in 2003, while in Kabardino-Balkaria it increased from 0.1 to more than 8 percent (Rosstat, 2004b). 
Table 1. Share of the North Caucasus in Russian National Economic Indicators, 1998 and 2004 (percent)

\begin{tabular}{lcccc}
\hline \hline \multicolumn{1}{c}{ Indicator } & \multicolumn{2}{c}{ North Caucasus } & \multicolumn{2}{c}{ Republics only } \\
& 1998 & 2004 & 1998 & 2004 \\
\hline Industrial production & 3.71 & 3.67 & 0.47 & 0.44 \\
Investments & 7.00 & 6.93 & 1.32 & 1.21 \\
Agric. production & 13.79 & 19.78 & 3.42 & 5.71 \\
Cereals & 21.28 & 29.92 & 1.57 & 2.44 \\
Sugar beets & 25.76 & 30.80 & 0.99 & 0.70 \\
Sunflower seeds & 49.71 & 50.28 & 1.20 & 1.53 \\
Vegetables & 12.63 & 16.48 & 4.63 & 8.28 \\
\hline
\end{tabular}

Source: Compiled by the authors from: Rosstat, 2006, multiple sections and pages.

Table 2. Selected Socioeconomic Indicators for the Regions of North Caucasus, 1990-2004

\begin{tabular}{|c|c|c|c|c|c|c|}
\hline \multirow{2}{*}{ Region } & \multicolumn{2}{|c|}{ Population, thous. } & \multirow{2}{*}{$\begin{array}{c}\text { GDP } \\
\text { per capita, } \\
2004^{\mathrm{a}}\end{array}$} & \multirow{2}{*}{$\begin{array}{c}\text { Per capita } \\
\text { monthly } \\
\text { income, } \\
2004^{b}\end{array}$} & \multicolumn{2}{|c|}{$\begin{array}{l}\text { Automobiles per } \\
1,000 \text { people }\end{array}$} \\
\hline & 1998 & 2004 & & & Units & $\begin{array}{l}\text { Change, } \\
\text { 2004:1990 }\end{array}$ \\
\hline Adygeya & 451 & 445 & 29,897 & 3,080 & 156.2 & 1.51 \\
\hline Karachayevo-Cherkessia & 440 & 437 & 33,218 & 3,344 & 129.5 & 1.70 \\
\hline Kabardino-Balkaria & 861 & 899 & 35,709 & 3,160 & 102.8 & 1.42 \\
\hline North Ossetia & 681 & 707 & 29,082 & 4,086 & 128.4 & 1.88 \\
\hline Ingushetia & 296 & 476 & 12,582 & 1,758 & 54.6 & 1.10 \\
\hline Chechnya & 1,167 & $1,121^{\mathrm{c}}$ & - & - & 41.6 & 0.84 \\
\hline Dagestan & 2,333 & 2,602 & 29,129 & 3,311 & 53.1 & 1.42 \\
\hline Krasnodar Kray & 5,128 & 5,106 & 52,192 & 4,379 & 190.4 & 2.36 \\
\hline Stavropol' Kray & 2,722 & 2,726 & 39,678 & 3,886 & 168.9 & 2.15 \\
\hline Rostov Oblast & 4,488 & 4,366 & 41,510 & 5,038 & 156.4 & 2.09 \\
\hline
\end{tabular}

aIn current rubles. Mean per capita GDP in Russia was 102,005 rubles.

bIn current rubles. Mean per capita income in Russia was 6,383 rubles.

'The population total enumerated for Chechnya in the 2002 census is disputed by some researchers as unrealistically high (e.g., see Maksudov, 2005).

Source: Compiled and calculated by the authors from Rosstat, 2006, multiple sections and pages.

As in much of the rest of Russia, the strengthening of internal economic inequalities in the regions of the North Caucasus has led to increasing social polarization. The constituent states of these regions vary significantly in terms of territory, population, ethnic composition, economic structures, means of production, and prosperity. The most apparent difference (Table 2) is the divide between "Russian" regions and the ethnic republics; in demographic and particularly economic indicators, Krasnodar and Stavropol' krays along with Rostov 
Oblast, are dominant. The poorest, predominantly agrarian territories in the region are wartorn Chechnya, Ingushetia, Dagestan, and Karachayevo-Cherkessia. ${ }^{20}$ Within the republics, contrasts are deepening between the capitals-with stronger economic structures, multiethnic populations, and stronger connections to Russian culture - and interior mountainous areas.

The North Caucasus and the territory to the north have traditionally formed a common energy and transportation infrastructure and inter-connected labor market. Although this connection has been weakened, two important transport axes remain, connecting the central regions of the former Soviet Union with the Transcaucasian republics (Polyan, 1988). ${ }^{21}$ Although currently blocked in places as a result of the conflicts between Georgia and Abkhazia and between Armenia and Azerbaijan, their importance to the development of the North Caucasus remains.

Another important economic factor in the continued integration of the North Caucasus is the region's potential as a tourist destination. But as long as the region is generally perceived as dangerous due to the potential for armed conflict and terrorism, ${ }^{22}$ the tourist trade will remain weak despite the region's evident cultural and environmental attractions. Small pockets of revival of tourism are now seen in the Mineral'nyye Vody region of Stavropol' Kray, ${ }^{23}$ Sochi in Krasnodar Kray, and in the mountains of Karachayevo-Cherkessia. ${ }^{24}$

\section{A CONTRADICTORY BALANCE SHEET}

In the contemporary North Caucasus, accumulating tensions in several of the republics close to Chechnya, in particular Dagestan, are visible. Despite a large amount of rhetoric about defeating terrorism and linking the conflicts in the region to the global war on terror (O'Loughlin et al., 2004), the Kremlin has not managed to define a clear political strategy. Relying on the "Kadyrovsty" (a local militia currently loyal to Moscow) as a key element of a "Chechenization" policy, the Putin administration recently declared victory. "We have scored a success in Chechnya .. . The problem has been solved," said Sergey Ivanov, then the defense minister (Chivers, 2007). ${ }^{25}$ But evidence that (unlike the first war of 1994-1996) the conflict is more geographically diffuse and involves multiple militias and gangs of uncertain criminal, political, and religious persuasions does not bode well for Moscow's aspirations (Lyall, 2006). Certainly, the rayons close to the Chechen border remain militarized, and roadblocks, document checks, and close police scrutiny remain the norm in the ethnic republics and in southern and eastern Stavropol' Kray.

In the five following papers in this special issue, we present both general and specific portraits of key aspects of the Caucasus region at the beginning of the $21^{\text {st }}$ century. In selecting these papers and authors, we were motivated by numerous, sometimes conflicting, considerations. An important criterion in forming the writing teams was to match Russian

\footnotetext{
${ }^{20}$ The presence of a substantial shadow economy in the republics does little to change their position relative to the Russian regions.

${ }^{21}$ The two run through the foothills of the North Caucasus and along the Black Sea coast.

${ }^{22}$ The U.S. State Department, for example, warns against travel to the region and prohibits U.S. government personnel from traveling there.

${ }^{23}$ According to Turizm (2005), there were 350,000 "organized" tourists in 2004.

${ }^{24}$ See Radvanyi and Muduyev (2007) in this special issue.

${ }^{25}$ Perhaps ironically, Ivanov was promoted to first deputy prime minister on the same day that the resignation of Chechen President Alu Alkhanov was announced (Myers, 2007a).
} 
authors with in-depth local understanding with Western scholars. Preliminary outlines and topics were identified in a series of meetings in Stavropol' in October 2005 and Kislovodsk in September 2006. Information for the papers was collected from a variety of sources because statistical yearbooks with aggregated data are rare and fugitive. Personal visits to the statistical offices of the republic and kray administrations were necessary. Interviews with local officials, conversations with residents, and a scientific sample of 2,000 North Caucasian residents (not including Chechnya and Ingushetia) also provided detailed information on current conditions.

Our second motivation for the selection of topics was the balance between general region-wide analysis of multiple topics and detailed consideration of important and individual local problems. We thus have two region-wide perspectives and two local analyses, as well as a fifth paper that compares geopolitical discourses about the region from local and national perspectives. A third consideration was that we wished to present numerous facets of the geography of the region by knowledgeable experts. Although (unfortunately) widely known as a place of numerous conflicts, there are many other aspects of the regional geography that demand attention in the wake of the dislocations caused by the disintegration of the Soviet Union. Thus, environmental factors, population decline and resettlement, economic adjustment to industrial collapse, social relations between ethnic groups, and the contrast between perceptions of political authorities in Moscow and ordinary local citizens are all featured in the papers that follow.

The paper by Jean Radvanyi and Shakmardan Muduyev (2007) adopts a wide perspective, both areally and topically. The authors favor a regional planning approach that is aware of common problems on both sides of the mountains and the evident impacts that changes in one country will have on its neighbors. They relate how the ongoing conflicts since the dissolution of the Soviet Union and newly marked and reinforced borders have disrupted traditional agricultural practices and promoted out-migration. Their general focus is on the quality of life for mountain residents, and they see some signs of recent improvements in the privatized economies while remaining cognizant of the vast problems of isolation, peripherality, poverty, and social unrest. The authors observe that modernization of infrastructure, whose neglect or abandonment proved to be the bane of earlier development plans, can still improve the lives of the residents and likely reduce the appeal of political radicals advocating massive social, religious, and political changes.

The paper by Olga Vendina, Vitaliy Belozerov, and Andrew Gustafson (2007) takes a more nuanced view of the Chechen conflicts than is normally found in the post-Soviet political science literature. Rather than focusing only on the causes and ebb/flow of the conflict or emphasizing the relationship between the federal center and the regions, they instead examine the externality effects of the conflict in both social and economic domains. Often when conflict is as pervasive and protracted as it is in the North Caucasus, the economic effects are less obvious. Because field work is impossible in Chechnya, the authors concentrate on the effects of the war on adjoining republics and Stavropol' Kray. Contrary to initial impressions, the war effects are not uniformly dire. Instead, there is a kind of "war and security" economy that has provided many jobs in a region of high employment and an underground economy that flourishes in the presence of large inflows of aid and subsidies for the local elites. Because, understandably, reliable data are difficult to acquire, the authors use other indicators of the state of the local economies and ethnic relations. Inasmuch as a large share of economic life is organized around the traditional clan and ethnic structures, economic changes and shifts have important implications for the state of ethnic relations. The authors analyze the "de-Russification" of the regions near Chechnya and indicate the social and 
demographic reasons for its growing importance over the past decade. They also discuss the pervasive criminality that has flourished given the weak authority of both the federal and republic governments.

The third paper by Vladimir Kolossov and Gerard Toal (2007) takes a critical geopolitical look at the explanation for political instability on Russia's southern borders, in the North Caucasus. Starting from the contention that geopolitical study requires the examination of geopolitical cultures and their interlocking networks of power, they contrast the discourses of the Chechen conflicts from the federal government with those represented by an array of political ideologies from far-left to far-right and with the explanations for the conflict provided by local citizens in a public opinion survey. These explanatory storylines are dramatically different from Putin administration statements that reflect a view that Russia acts legitimately and follows international norms. According to this view, territorial self-defense of a region, portrayed as both historically part of Russia and occupying a special place in the Russian psyche, is thus natural and Russia is therefore a key ally in the international war on terror. Critics of the Putin claims on the left and right stress differentially human rights abuses, the cultural differences between Russians and Caucasians, the strategic implications of successful separatism, the loss of the Soviet heritage, and the role of outsiders in promoting instability in an already tense region. Locals, in contrast to these external views, emphasize economic problems that have led to instability: over half of those who responded believe that poverty is the main explanation for conflict.

The first of the local studies, of Dagestan by Eldarov et al. (2007), examines migration in the context of the history of both forced settlement to meet Soviet ethnic and economic planning goals and more recent voluntary migration from mountains to plains (cities) to secure employment. Dagestan remains one of the poorest subjects of the Russian Federation and relies on the central government transfers for the vast majority of its budget. While much of the literature in the West on Dagestan has concentrated on its political life, especially the rise of political Islam strongly affected by the war in neighboring Chechnya, the authors prefer to stress the consociational arrangements in place that allow the multiplicity of nationalities access to political and economic resources. A strong Dagestani identity is overlaid on the ethnic one, and in our surveys a plurality of Dagestani respondents identified themselves first as Russian citizens. Migration from mountainous mono-ethnic villages for economic reasons to the melting pots of urban Dagestan has helped to reduce ethnic isolation. Analysis of the survey responses from the December 2005 survey of Dagestani residents about their migration intentions confirms that economic incentives - as well as other traditional explanations for migration such as age, gender, and education - account for the current trends.

The final paper by John O'Loughlin, Alexander Panin, and Frank Witmer (2007) offers a parallel study to that of Dagestan by examining ethnic changes and migration in another large territory of the North Caucasus, namely Stavropol' Kray. The themes introduced by Vendina et al. (2007) regarding de-Russification are examined using rayon-level data and yearly data on in- and out-migration by nationality. Generally, the southern and eastern regions of the kray close to Chechnya have experienced the greatest declines in their Russian populations but these areas have also seen a marked reduction in agricultural output and (in the cities) industrial collapse. Larger cities in the north and west have continued to attract Russian in-migrants and, more recently, settlers from other ethnic groups. Although during the early 1990s, in the immediate aftermath of the collapse of the Soviet Union, the territory received significant numbers of Russians migrating from the Near Abroad, recent years have seen a strong and apparently irreversible population decline of Russians, accompanied by stable or slightly growing numbers of other ethnicities. A detailed aggregate data study of a 
typical agricultural rayon in the northwest of the kray (coincidentally the birth place of Mikhail Gorbachev), and analysis of the preferences and plans of the survey respondents from the kray, demonstrate that it is economic opportunities elsewhere and limited chances at home that underlie most migration decisions. As in other parts of the region, the average citizen is much more worried about the economic future than political or ethnic questions.

Taken together, we hope that these papers offer a somewhat unconventional account of the Caucasus, because we do not dwell on the details of the regional conflicts that dominate the Western literature on the region. We have attempted to provide insights from "inside" the region through the opinions of local residents and the insights of regional experts. The overall balance sheet is much more complicated than the usual narratives focusing on the federal center-ethnic regions dichotomy, ethnic rivalries, or growing religious fundamentalism. The region's history and geography are very complex, and developments at the present continue to add to these complexities.

\section{REFERENCES}

Abdulagatov, Zaid, "Wahhabism and Jadidism in Islamic Consciousness in Daghestan: Parallels and Contradictions," Central Asia and the Caucasus, 6, 42: 92-102, 2006.

Animitsa, Yevgeniy G. and Aleksandr T. Tertyshnyy, Mestnoye samoupravleniye: Istoriya $i$ sovremennost' (Local Self-Government: History and Modernity). Yekaterinburg, Russia: Urals University Press, 1998.

Belozerov, Vitaliy S., Etnodemograficheskie protsessy na Severnom Kavkaze (Ethno-demographic Processes in the North Caucasus). Stavropol', Russia: Stavropol' University Press, 2000.

Belozerov, Vitaliy S., Etnicheskaya karta Severnogo Kavkaza (Ethnic Map of the North Caucasus). Moscow, Russia: OGI, 2005.

Belozerov, Vitaliy S., Petr P. Touroun, Tamara A. Galkina, and Vladimir A. Kolossov, "Les Diasporas Armeniènne et Grecque dans la Mosaïque Ethnique du Caucase du Nord (The Armenian and Greek Diasporas in the Ethnic Mosaic of the North Caucasus)" Révue Europeenne des Migrations Internationales, 14, 3:103-125, 1998.

Beroutchachvili, Nikolai and Jean Radvanyi, Atlas Géopolitique du Caucase (Geopolitical Atlas of the Caucasus), first ed. Paris, France: Publications Langues'O, 1998.

Brunet, Roger, Denis Eckert, and Vladimir Kolossov, eds., Atlas de la Russie et les Pays Proches (Atlas of Russia and the Near Abroad). Paris, France: Documentation Française, 1995.

Carrère d'Encosse, Hélène, The End of the Soviet Empire: The Triumph of the Nations. New York, NY: Basic Books, 1993.

Chivers, C. J., "Russian Defense Chief Declares Victory in Chechnya," International Herald Tribune, February 12, 2007.

Denisova, Galina S. and Viktor P. Ulanov, Russkiye na Severnom Kavkaze: Analiz transformatsii sotsio-kulturnogo statusa (Russians in the North Caucasus: Analysis of Transformation of Socio-cultural Status). Rostov-na-Donu, Russia: Rostov State Pedagogical University Press, 2003.

Drobizheva, Leokadiya M., Airat R. Aklayev, Viktoriya V. Koroteyeva, and Galina U. Soldatova, Demokratizatsiya i obrazy natsionalizma $v$ Rossiyskoy Federatsii 1990-kh godov (Democratization and Forms of Nationalism in the Russian Federation in the 1990s). Moscow, Russia: Mysl', 1996.

Druzhinin, Aleksandr, Yug Rossii kontsa XX-nachala XXI veka (ekonomichesko-geograficheskiye aspekty) (The South of Russia in the Late XX-Early XXI Century [Economic-Geographic Aspects]). Rostov-na-Donu, Russia: Rostov State University Press, 2005.

Druzhinin, Aleksandr G. and Yuriy S. Kolesnikov, eds., Yug Rossii na rubezhe tret'yego tysyacheletiya (The South of Russia on the Threshold of the Third Millenium). Rostov-na-Donu, Russia: Rostov State University Press, 2000. 
Eldarov, Eldar M., Edward C. Holland, Sharafudin M. Aliyev, Zaid M. Abdulagatov, and Zagir V. Atayev, "Resettlement and Migration in Post-Soviet Dagestan," Eurasian Geography and Economics, 48, 2:226-248, 2007.

Hille, Christian M. L., State Building in the Transcaucasus since 1917. Leiden, The Netherlands: Leiden University Press, 2003.

Hirsch, Francine, Empire of Nations. Ethnographic Knowledge and the Making of the Soviet Union. Ithaca, NY: Cornell University Press, 2005.

Hunter, Shireen T., "Borders, Conflict, and Security in the Caucasus: The Legacy of the Past," SAIS Review, 26, 1:111-125, 2006.

Inozemtsev, Pyotr and Dmitry Litovkin, "We've Given Up the Base: Russia No Longer Has Any Military Installations in Georgia," Izvestiya, May 31, 2005, 1-2 (translated in Current Digest of the Post-Soviet Press), June 29, 2005, 15-16.

Kaiser, Robert J., The Geography of Nationalism in Russia and the USSR. Princeton, NJ: Princeton University Press, 1994.

Karavayev, Sergey A., Etnogeograficheskiye protsessy na Kavkaze v XX veke (Ethno-geographic Processes in the Caucasus in the XX Century). Doctoral thesis, Moscow State University, Faculty of Geography, 2006.

Kolossov, Vladimir, Tamara Galkina, and Mikhail Kouibychev, "La géographie des diasporas: une approche théorique et l'exemple des diasporas juive, arménienne et grecque dans l'ex-URSS (The Geography of Diasporas: A Theoretical Approach and Example of the Jewish, Armenian, and Greek Diasporas in the Former USSR)," in Michel Bruneau, ed., Diasporas (Diasporas). Paris, France: RECLUS-La Documentation Française, 1995, 132-150.

Kolossov, Vladimir, Tamara Galkina, and Alexei Krindatch, "Les Grecs du Sud de la Russie et du Caucase: Peuplement, Répartition, Territorialité (The Greeks in Southern Russia and the Caucasus: Population, Distribution, Territoriality)," in Michel Bruneau, ed., Les Grecs Pontiques: Diaspora, Identité, Territoires (The Black Sea Greeks: Diaspora, Identity, Territories). Michel Bruneau, Ed.: CNRS Editions, Paris, pp. 91-112, 1998.

Kolossov Vladimir, Olga Glezer, and Nikolai Petrov, Ethnoterritorial Conflicts in the Former USSR. Durham, UK: IBRU Press, 1992.

Kolossov, Vladimir and Nikolai Mironenko, Geopolitika i politicheskaya geografiya (Geopolitics and Political Geography). Moscow, Russia: Aspekt Press, 2001.

Kolossov, Vladimir and Gerard Toal (Gearóid Ó Tuathail), “An Empire's Fraying Edge? The North Caucasus Instability in Contemporary Russian Geopolitical Culture," Eurasian Geography and economics, 48, 2:202-225, 2007.

Kramer, Mark, "Guerrilla Warfare, Counterinsurgency, and Terrorism in the North Caucasus: The Military Dimension of the Russian-Chechen Conflict," Europe-Asia Studies, 57, 2:209-290, March 2005.

Lenin, Vladimir I., Itogi diskussii o samoopredelenii (Results of a Discussion on Self-Determination). Moscow, Russia: Politizdat, Polnoye sobraniye sochinenii (Complete Collected Works), 30:18-21, 1962.

Longuet-Marx, Frederique, ed. Caucase: Axes anciens, nouveaux enjeux (The Caucasus: Old Axes, New Networks). Geneva, Switzerland: CRES, Nouveaux Mondes, no. 8, 1998.

Lyall, Jason, "Landscapes of Violence: A Comparative Study of Insurgency in the Northern Caucasus." Paper presented at the Midwest Political Science Association meetings, Chicago, Illinois, April 2006.

Lynch, Dov, ed., The South Caucasus: A Challenge for the EU. Paris, France: Institute for Security Studies, Cahiers de Chaillot, no. 65, 2003.

Maksudov, Sergey, "Naseleniye Chechni: prava li perepis'? (The Population of Chechnya: Is the Census Correct?)," Demoscope, November 2, 2005 [http://www.demoscope.ru/weekly/2005/0211/ tema04.php]. 
Matsuzato, Kimitaka and Magomed-Rasul Ibragimov, "Islamic Politics at the Sub-regional Level in Dagestan: Tariqa Brotherhoods, Ethnicities, Localism, and the Spiritual Board," Europe-Asia Studies, 57, 5:743-779, July 2005.

Mendelson, Sarah, "Anatomy of Ambivalence: The International Community and Human Rights Abuse in the North Caucasus," Problems of Post-Communism, 53, 6:3-15, 2006.

Muduyev, Shakhmardan S., Naseleniye i khozyaystvo Dagestana na rubezhe vekov (Population and Economy of Dagestan at the Turn of the Centuries). Makhachkala, Russia: Dagestani Book Press, 2003.

Mukomel, Vladimir, Migratsionnaya politika Rossii: Postsovetskiye konteksty (Russia's Migration Policy: Post-Soviet Contexts). Moscow, Russia: Institute of Sociological Studies of the Russian Academy of Sciences, 2005.

Myers, Steven Lee, "Putin, Promoting an Ally, Fuels Speculation over Successor," The New York Times, February 16, 2007a, A10.

Myers, Steven Lee, "Putin Picks Premier Tied to Abuse as Chechen Leader," The New York Times, March 2, 2007b, A6.

Nabiyeva, Umukusum N., Kul turnaya geografia Dagestana (Cultural Geography of Dagestan). Moscow, Russia: Institute of Natural and Cultural Heritage, 2005.

Nabiyeva, Umukusum N., Faktory formirovaniya i sovremennaya struktura geokul'turnogo prostranstva Dagestana (Factors in the Creation and Contemporary Structure of the Geocultural Space of Dagestan). Doctoral thesis, Institute of Geography, Russian Academy of Sciences, 2006.

Nikitina, Larisa, Ksenya Veretennikova, Vera Sitnina, and Mikhail Vorobyov, "Subjects of the Federation: Dmitriy Kozak Hopes to Defeat Terrorism and Poverty in Russia's Regions with the Help of External Management," Vremya Novosti, July 20, 2005, 1-2 (translated in Current Digest of the Post-Soviet Press, August 24, 2005, 4-5).

O'Loughlin, John, Gearóid Ó Tuathail, and Vladimir Kolossov "Russian Geopolitical Storylines and Public Opinion in the Wake of 9-11," Communist and Post-Communist Studies, 37, 3:281318, 2004.

O'Loughlin, John, Alexander Panin, and Frank Witmer, "Political Change and Migration in Stavropol' Kray: The Effects of Regional Conflicts and Economic Restructuring," Eurasian Geography and Economics, 48, 2:249-267, 2007.

Polyan, Pavel M., Naseleniye i rasseleniye gornykh rayonov (Population and Settlement of Mountainous Regions). Moscow, Russia: Nauka, 1988.

Polyan, Pavel M., Ne po svoyey vole: Istoriya i geografiya prinuditel'nykh migratsii v SSSR (Not by Their Own Will: A History and Geography of Forced Migrations in the USSR). Moscow, Russia: OGI Memorial, 2001.

Radvanyi, Jean, “Grand Caucase, la 'montagne des peuples' écartelée (Great Caucasus, the 'Mountain of Peoples' Divided)”, in Géopolitique des montagnes (Geopolitics of the Mountains): Hérodote 107: 65-88, 2002.

Radvanyi, Jean and Shakhmardan S. Muduyev, "Challenges Facing Mountain Peoples of the Caucasus," Eurasian Geography and Economics, 48, 2:157-177, 2007.

Rosstat (Federal'naya sluzhba gosudarstvennoy statistiki), "Osnovnyye itogi vserossiyskoy perepisi naseleniya 2002 (The 2002 All-Russia Population Census Main Results)” [http:// www.perepis2002ru/], 2004a.

Rosstat (Federal'naya sluzhba gosudarstvennoy statistiki), Regiony Rossii 2003 (Regions of Russia 2005). Moscow, Russia, Rosstat, 2004b.

Rosstat (Federal'naya sluzhba gosudarstvennoy statistiki), Regiony Rossii 2005 (Regions of Russia 2005). Moscow, Russia, Rosstat, 2006.

Rowland, Richard H., "Recent Demographic Trends in Armenia: Results of the 2001 Census and Update to 2006," Eurasian Geography and Economics, 48, 1:73-94, 2007.

Ryazantsev, Sergey V., Sovremennyy demograficheskiy i migratsionnyy portret Severnogo Kavkaza (Contemporary Demographic and Migration Portrait of the North Caucasus). Stavropol', Russia: Serviseshkola, 2003. 
Sakwa, Richard, ed., Chechnya: From Past to Future. London, UK: Anthem Press, 2005.

Tarkhov, Sergey A., "Istoricheskaya evolutsiya administrativno-territorial'nogo deleniya Rossii (Historical Evolution of the Territorial-Administrative Division of Russia)," in Regionalizatsiya $v$ razvitii Rossii. Geograficheskiye protsessy i problemy (Regionalization in the Development of Russia. Geographical Processes and Problems). Moscow, Russia: OGI Press, 2001 190-213.

Tishkov, Valery A., Ethnicity, Nationalism, and Conflict in and after the Soviet Union: The Mind Aflame. London, UK: Sage, 1997.

Tishkov, Valery A., "The Use and Misuse of Typologies and Data," Journal of Peace Research, 36, 5: 1-21, September 1999.

Tishkov, Valery A., Obshchestvo v vooruzhennom konflikte. Etnografiya chechenskoy voiny (Society in an Armed Conflict: Ethnography of the Chechen War). Moscow, Russia: Nauka, 2001.

Tishkov, Valery A., Chechnya: Life in a War-Torn Society. Berkeley, CA: University of California Press, 2005.

Turizm i turisticheskiye resursy v Stavropol'skom kraye. Statisticheskiy sbornik (Tourism and Tourist Resources in Stavropol' Kray: A Statistical Collection). Stavropol', Russia: Stavropol' Kray Committee on Statistics, 2005.

Vendina, Olga I., Vitaliy S. Belozerov, and Andrew Gustafson, "The Wars in Chechnya and Their Effects on Neighboring Regions," Eurasian Geography and Economics, 48, 2:178-201, 2007.

Ware, Robert and Enver Kisirev, "The Islamic Factor in Dagestan," Central Asian Survey, 19, 2: 235-252, June 2000.

Ware, Robert Bruce, Enver Kisirev, Werner J. Patzelt, and Ute Roericht, "Political Islam in Dagestan," Europe-Asia Studies, 55, 2:287-302, March 2003. 